J Arid Land (2013) 5(3): 298-309

doi: $10.1007 / \mathrm{s} 40333-013-0172-0$

jal.xjegi.com; www.springer.com/40333

\title{
Annual-perennial plant relationships and species selection for desert restoration
}

\author{
Scott R ABELLA ${ }^{1 *}$, Stanley D SMITH ${ }^{2}$ \\ ${ }^{1}$ Department of Environmental and Occupational Health, University of Nevada Las Vegas, Las Vegas, Nevada 89154-3064, USA \\ ${ }^{2}$ School of Life Sciences, University of Nevada Las Vegas, Las Vegas, Nevada 89154-4004, USA
}

\begin{abstract}
Exotic plant invasion is a growing concern in the conservation and management of indigenous arid land ecosystems. By creating areas of ameliorated microclimates and fertile soil below their canopies, perennial plants might influence exotic annual plant invasions. We conducted a quantitative literature review of studies that compared exotic annual plant abundance among native perennial plant species and interspace (open areas) microsites in North America's Mojave Desert, where exotic plant invasion has corresponded with increasing extent of wildfire and broad-scale ecosystem transformation. Ten studies compared exotic annual plant abundance between interspaces and below a total of 36 native perennial species. These studies revealed that: (1) With few exceptions, most native perennial species supported a greater abundance of exotic annuals than interspaces, indicating overall facilitation of exotic species by native perennials. (2) Exotic species abundance varied by orders of magnitude among native perennial species, with some perennial species harboring amounts of exotics similar to interspaces. (3) Distributions of dominant exotic species varied, where Bromus rubens displayed a greater affinity for below-perennial microsites than did Schismus spp. and Erodium cicutarium that often were most abundant in interspaces. Results suggest that the degree of facilitation of exotic plants warrants consideration when selecting native perennial species for revegetation and restoration projects.
\end{abstract}

Keywords: Bromus rubens; exotic; fertile island; invasive; nurse plant; positive plant interaction; Schismus

Citation: Scott R ABELLA, Stanley D SMITH. 2013. Annual-perennial plant relationships and species selection for desert restoration. Journal of Arid Land, 5(3): 298-309.

A major principle of arid land ecology is that locations of perennial plants influence spatial distributions of microclimate, soil properties, and organisms (Tielbörger and Kadmon, 1997; Flores and Jurado, 2003; Allen et al., 2011). Through shading, microclimates below many perennial plant canopies exhibit moderated temperatures, reduced solar insolation, and lower evaporation rates compared to interspaces between perennial plants (Franco and Nobel, 1989). Via stemflow and root macrochannels, perennial plants also can increase water infiltration during precipitation events (Devitt and Smith, 2002; Bhark and Small, 2003). Soil nutrients are often more concentrated below perennial plants, through several processes such as trapping of dust and litter, root uptake of nutrients from interspaces, and enhanced litter decomposition (Schlesinger et al., 1996; Titus et al., 2002; Yin et al., 2010). These nutrient-enriched soils are termed "fertile islands" and create heterogeneity in soil fertility at spatial scales of $<1 \mathrm{~m}$ to a few meters (Garner and Steinberger, 1989). As a result of these environments, biota such as soil microbes and annual plants are often most abundant below perennial plant canopies (Patten, 1978; Tewksbury and Lloyd, 2001; Su et al., 2012). Fertile islands further contain large soil seed banks and are key locations for plant recruitment (Nelson and Chew, 1977; De Soyza et al., 1997; Holzapfel et al., 2006).

*Corresponding author: Scott R ABELLA (E-mail: scott.abella@unlv.edu) Received 2012-10-04; revised 2013-01-10; accepted 2013-02-25

(C) Xinjiang Institute of Ecology and Geography, Chinese Academy of Sciences, Science Press and Springer-Verlag Berlin Heidelberg 2013 
In disturbed desert areas where ecological restoration is a goal, many authors have noted the importance of reestablishing fertile islands to initiate ecosystem recovery (Padilla and Pugnaire, 2006; Bonanomi et al., 2011). Invasions by exotic plants have complicated this fundamental aspect of desert restoration. Although fertile islands are key locations for native plant recruitment, they are also hospitable environments for many exotic species that thrive in nutrient-enriched soils (Brooks, 1999; Allen et al., 2011). In arid lands such as the Mojave Desert of North America, exotic annual species (e.g. Bromus rubens and Brassica tournefortii) can outcompete native annuals (Fig. 1; Brooks, 2000; Barrows et al., 2009). Moreover, the exotic annuals derive overall net facilitative benefits from native perennial plants, whereas the exotics reduce fitness of the native perennial more than native annuals do (Holzapfel and Mahall, 1999; DeFalco et al., 2007; Rodríguez-Buriticá and Miriti, 2009).

Two potential sources of variation to the pattern of annual-perennial plant relationships are that abundance of annuals might vary below different perennial species and that not all exotic species are spatially distributed the same way. Bromus rubens and Schismus spp., for example, both dominant exotic annual taxa in the Mojave Desert, differ in their resource acquisition and germination strategies. Schismus is more like most native annual species with its conservative use of soil resources and greater seed dormancy than Bromus (Esque and Schwalbe, 2002). Compared to Bromus, these adaptations likely allow Schismus to better exploit infertile soil and maintain longer-lived seed banks in interspaces which might have longer intervals between suitable years for plant establishment than on fertile islands. Traits of native perennials also vary among species. Differences among perennial species in canopy architecture, rooting depth, $\mathrm{N}$ fixation, litter chemistry, and affiliations with animals could induce variation to the amount of annual plants perennial species harbor below their canopies (Went, 1942; McAuliffe, 1988; Bonanomi et al., 2011).

Clarifying annual-perennial plant relationships could produce several benefits, such as framing hypotheses for mechanistic research regarding why distributions of exotic plants differ and why some native perennial species facilitate exotic plant invasions more than others. Furthermore, a fundamental question when reestablishing native vegetation as part of ecological restoration is which native species to use. Especially when treatments (e.g. herbicide) to control an exotic species are limited, one criterion for native species selection could be the degree that a native species facilitates exotic plants. Ecological restoration might thus select native species that do not promote exotics or use mixtures of native perennials to optimize ability to facilitate native plant recruitment, while minimizing exotic species facilitation (Abella et al., 2012). We conducted a quantitative literature review, using reproducible literature search and data-gathering techniques, to assess relationships of native perennial plants with exotic annuals in the Mojave Desert of southwestern North America. We sought to identify (1) differences in distribution among exotic annual species and community measures relative to locations of interspaces and native perennial plants, and (2) the relative amounts of exotic annuals harbored by a range of native perennial species.

\section{Study area and methods}

\subsection{Study area}

The $1.24 \times 10^{5} \mathrm{~km}^{2}$ Mojave Desert is in the southwestern USA (Fig. 1). This hot desert receives most of its rainfall in cool months from October to April, which also is the growing season for winter annual plants (Rundel and Gibson, 1996). Differing from some deserts such as China's Taklimakan Desert, sand dunes are rare and topography is dominated by bajadas (coalesced alluvial fans), piedmonts, and low mountains. Physiognomy is desert scrub, with Larrea tridentata or L. tridentata-Ambrosia dumosa as dominant vegetation types and mixed perennial communities also important. Joshua tree (Yucca brevifolia), other Yucca species, and cacti (Ferocactus and Opuntia spp.) are locally abundant. Winter annuals constitute the total or dominant annual plant flora, as summer annuals are rare compared to winter annuals in most areas (Smith et al., 1997). Widespread exotic annual species include Bromus rubens, Schismus arabicus, Schismus barbatus, Brassica tournefortii, and Erodium cicutarium, with others, such as Bromus berteroanus, locally abundant (Brooks, 1999; Esque 
and Schwalbe, 2002; Barrows et al., 2009). Although Bromus rubens is a primary fuel-producing species that facilitates wildfire spread, the other exotic annual species also can provide fuel and compete with native species (Barrows et al., 2009). Examples of common native annuals include Amsinckia tessellata, Cryptantha pterocarya, Chaenactis fremontii, Plantago ovata, Vulpia octoflora, and many Eriogonum and Phacelia spp. Some of the many animal inhabitants include Merriam's kangaroo rat (Dipodomys merriami), black-tailed jackrabbit (Lepus californicus), bighorn sheep (Ovis canadensis), coyote (Canis latrans), desert tortoise (Gopherus agassizii), and an array of invertebrates, most of which concentrate their nesting and feeding activity in shrub fertile-island microhabitats (Rundel and Gibson, 1996).

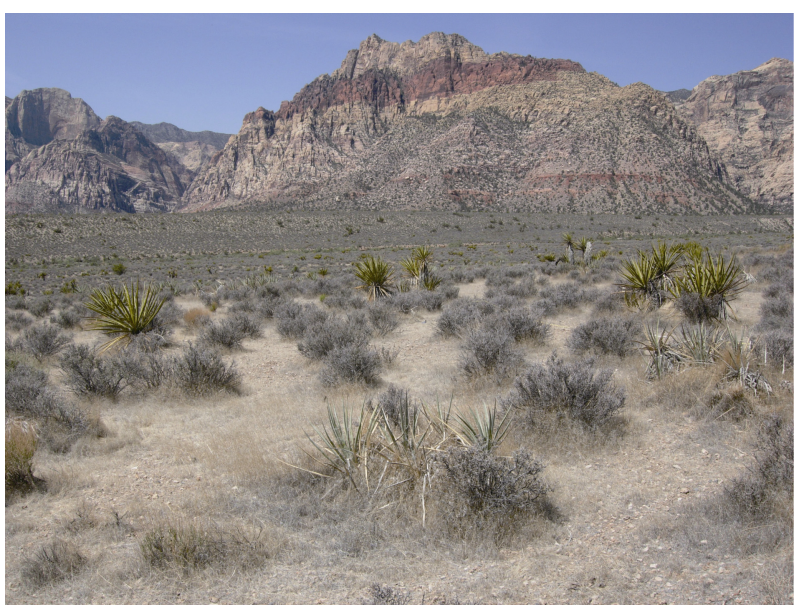

Fig. 1 Mojave Desert site containing the native perennials Coleogyne ramosissima (gray, compact shrubs in the front half of the photo), Yucca baccata (light-bluish green and spiked, center foreground), and Yucca schidigera (dark green and spiked, center of photo) supporting heavy fuel loads of the exotic annual grass Bromus rubens below their canopies. Interspaces between shrubs primarily contain the exotic annual grasses Schismus spp. and some Bromus, increasing fuel continuity between shrubs. Photo by ABELLA S R, May 2007 at the time of senescence of the winter exotic annual grasses, in Red Rock Canyon National Conservation Area, 15-km west of Las Vegas, Nevada, USA.

\subsection{Data synthesis}

We identified published papers for inclusion in the analysis by searching in December 2012 the article databases of Academic Search Premier (coverage 1975-present), Agricola (1400s-present), Google Scholar (http://scholar.google.com/; all years), ScienceDirect (variable years), and Web of Knowl- edge (1899-present). We used combinations of the following search terms in the article titles or key words: fertile island, perennial, annual, shrub, nurse, facilitation, positive plant interaction, recruitment, relationship, invasibility, Bromus rubens, Schismus, Brassica tournefortii, Erodium cicutarium, and Mojave. We also searched reference lists of located papers for other applicable references. To qualify as data for inclusion in the review, a study had to meet all of the following: (1) to be conducted in the Mojave Desert or adjacent transitional Colorado Desert (western Sonoran) (Fig. 2); (2) to report quantitative data on abundance of one or more exotic annual species or exotic community measures below one or more native perennial species, with data distinguished by perennial species (i.e. species were not lumped together); and (3) to include interspaces for comparison. We calculated a ratio of exotic species abundance below perennial to interspace (below perennial: interspace) for each species or community measure in each study. We augmented available data by contacting authors of papers wherever possible. We were able to obtain data in this personal communication manner for: Schismus barbatus weight of aboveground biomass (collected on $0.02-\mathrm{m}^{2}$ plots described in the publication) to augment density reported in Rodríguez-Buriticá and Miriti (2009); and exotic annual abundance below four additional perennial species that occupied $\geq 3$ sites part of Craig et al. (2010). For each study that met inclusion criteria, we also calculated a below perennial: interspace ratio for native annual species for studies reporting data for native annuals.

\section{Results and discussion}

\subsection{Description of the literature}

Eight studies with publication dates ranging from 1999 to 2012 met inclusion criteria for exotic annual vegetation and another two studies published in 1977 and 2009 met inclusion criteria for exotic annual seed banks (Fig. 2, Table 1). The number of native perennial species examined within a study ranged from one (Brooks, 1999; Brooks, 2000a; Rodríguez-Buriticá and Miriti, 2009; Steers and Allen, 2010; Schafer et al., 2012) to 16 (Abella et al., 2011) and 29 species 


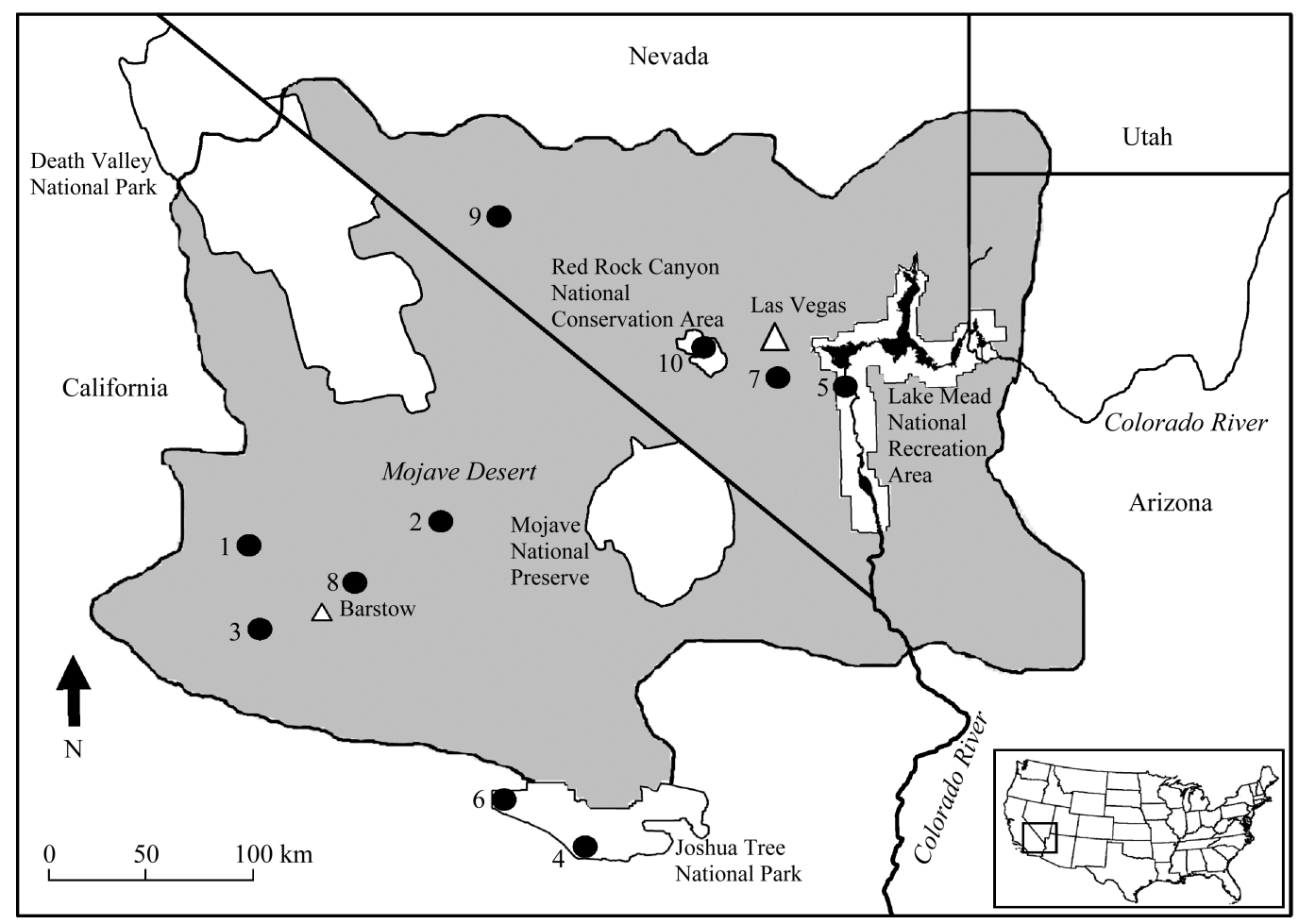

Fig. 2 Locations of studies that have compared exotic annual plant species abundance between interspaces and below one or more native perennial species in the Mojave Desert, USA. Study 1, Brooks (1999); 2, Brooks (2000a); 3, Brooks (2009); 4, Rodríguez-Buriticá and Miriti (2009); 5, Craig et al. (2010); 6, Steers and Allen (2010); 7, Abella et al. (2011); 8, Schafer et al. (2012); 9, Nelson and Chew (1977); and 10, Abella et al. (2009). For studies conducted at multiple sites (e.g. Brooks, 2000a; Abella et al., 2011), a centrally located site is shown on the map.

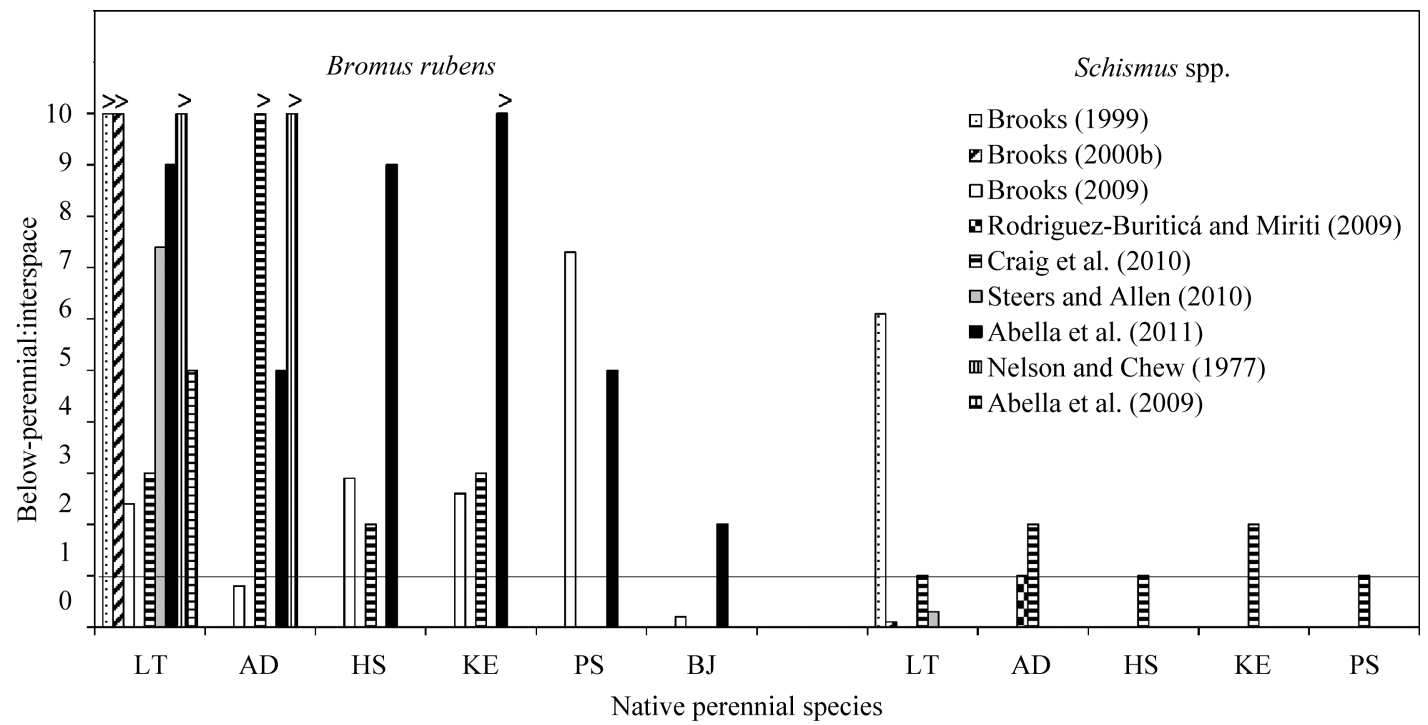

Fig. 3 Comparison of distributions of the exotic annual grasses Bromus rubens and Schismus spp. among common native perennial species relative to interspaces in the Mojave Desert, USA. The $y$-axis is the ratio of the abundance of the exotic annual below a native perennial compared to interspaces. Values of this ratio greater than 1 indicate that the annual species is more abundant below the perennial than in interspaces. Blanks indicate that a study did not measure a particular perennial species. The '>' symbols above bars indicate that a ratio is greater than 10. Perennial species are abbreviated as: LT, Larrea tridentata; AD, Ambrosia dumosa; HS, Hymenoclea salsola; KE, Krameria erecta; PS, Psorothamnus fremontii; and BJ, Bebbia juncea. Data for 1995 and 1997 were used for Brooks (1999) and Brooks (2000a). 
Table 1 Summary of studies comparing annual plant measures between interspaces and below perennial plant species in the Mojave Desert, USA

\begin{tabular}{|c|c|c|c|c|c|c|c|c|c|c|c|c|c|c|c|c|c|c|c|}
\hline \multirow{2}{*}{ Study and measure (interspace value) ${ }^{1}$} & \multicolumn{19}{|c|}{ Native perennial species } \\
\hline & $\overline{\mathrm{LT}^{2}}$ & $\mathrm{AD}$ & HS & $\mathrm{KE}$ & $\mathrm{KG}$ & PS & BJ & $\mathrm{CR}$ & $\mathrm{EF}$ & $\mathrm{EV}$ & ET & ES & GS & MS & PR & SM & $\mathrm{TM}$ & LA & YS \\
\hline Brooks $(1999)^{3}$ & $\longrightarrow$ & 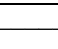 & & & 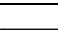 & Bel & w-pe & renni & al : i & ters & ace & bund & ance & ratio & 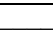 & + & 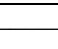 & - & - \\
\hline 1994 exotic richness $\left(1.5 / 0.1 \mathrm{~m}^{2}\right)$ & 0.5 & & & & & & & & & & & & & & & & & & \\
\hline 1995 exotic richness $\left(1.6 / 0.1 \mathrm{~m}^{2}\right)$ & 1.3 & & & & & & & & & & & & & & & & & & \\
\hline 1994 exotic biomass $\left(20 \mathrm{~kg} / \mathrm{hm}^{2}\right)$ & 0.3 & & & & & & & & & & & & & & & & & & \\
\hline 1995 exotic biomass $\left(13 \mathrm{~kg} / \mathrm{hm}^{2}\right)$ & 9.2 & & & & & & & & & & & & & & & & & & \\
\hline 1994 Bromus rubens biomass $\left(0.6 \mathrm{~kg} / \mathrm{hm}^{2}\right)$ & 2.1 & & & & & & & & & & & & & & & & & & \\
\hline 1995 Bromus rubens biomass $\left(0.4 \mathrm{~kg} / \mathrm{hm}^{2}\right)$ & 37.1 & & & & & & & & & & & & & & & & & & \\
\hline 1994 Bromus berteroanus biomass $\left(<0.1 \mathrm{~kg} / \mathrm{hm}^{2}\right)$ & 28.8 & & & & & & & & & & & & & & & & & & \\
\hline 1995 Bromus berteroanus biomass $\left(0.4 \mathrm{~kg} / \mathrm{hm}^{2}\right)$ & 18.3 & & & & & & & & & & & & & & & & & & \\
\hline 1994 Schismus spp. biomass $\left(9 \mathrm{~kg} / \mathrm{hm}^{2}\right)$ & 0.1 & & & & & & & & & & & & & & & & & & \\
\hline 1995 Schismus spp. biomass $\left(9 \mathrm{~kg} / \mathrm{hm}^{2}\right)$ & 6.1 & & & & & & & & & & & & & & & & & & \\
\hline 1994 Erodium cicutarium biomass $\left(12 \mathrm{~kg} / \mathrm{hm}^{2}\right)$ & 0.3 & & & & & & & & & & & & & & & & & & \\
\hline 1995 Erodium cicutarium biomass $\left(4 \mathrm{~kg} / \mathrm{hm}^{2}\right)$ & 13.6 & & & & & & & & & & & & & & & & & & \\
\hline \multicolumn{20}{|l|}{ Brooks $(2000 a)^{4}$} \\
\hline 1996 Bromus rubens biomass $(<0.1$ g/m²) & 200 & & & & & & & & & & & & & & & & & & \\
\hline 1997 Bromus rubens biomass $\left(0.5 \mathrm{~g} / \mathrm{m}^{2}\right)$ & 300 & & & & & & & & & & & & & & & & & & \\
\hline 1996 Schismus spp. biomass $\left(9 \mathrm{~g} / \mathrm{m}^{2}\right)$ & 0.1 & & & & & & & & & & & & & & & & & & \\
\hline 1997 Schismus spp. biomass $\left(18 \mathrm{~g} / \mathrm{m}^{2}\right)$ & 0.1 & & & & & & & & & & & & & & & & & & \\
\hline 1996 Erodium cicutarium biomass $\left(5 \mathrm{~g} / \mathrm{m}^{2}\right)$ & 0.1 & & & & & & & & & & & & & & & & & & \\
\hline 1997 Erodium cicutarium biomass $\left(30 \mathrm{~g} / \mathrm{m}^{2}\right)$ & 0.1 & & & & & & & & & & & & & & & & & & \\
\hline 1996 Amsinckia tesselata biomass $\left(0.5 \mathrm{~g} / \mathrm{m}^{2}\right)^{*}$ & 2.0 & & & & & & & & & & & & & & & & & & \\
\hline 1997 Amsinckia tesselata biomass $\left(2 \mathrm{~g} / \mathrm{m}^{2}\right)^{*}$ & 8.0 & & & & & & & & & & & & & & & & & & \\
\hline \multicolumn{20}{|l|}{ Brooks $(2009)^{5}$} \\
\hline Bromus rubens biomass $\left(91 \mathrm{~kg} / \mathrm{hm}^{2}\right)$ & 2.4 & 0.8 & 2.9 & 2.6 & & 7.3 & 0.2 & 4 & & & & 2 & & & & 6.7 & 5.3 & 8.4 & 10.1 \\
\hline \multicolumn{20}{|l|}{ Rodríguez-Buriticá and Miriti (2009) } \\
\hline Schismus barbatus density $\left(868 / \mathrm{m}^{2}\right)$ & & 0.9 & & & & & & & & & & & & & & & & & \\
\hline Schismus barbatus biomass $\left(32 \mathrm{~g} / \mathrm{m}^{2}\right)$ & & 1.0 & & & & & & & & & & & & & & & & & \\
\hline \multicolumn{20}{|l|}{ Craig et al. (2010) } \\
\hline Exotic richness $\left(1 / 0.25 \mathrm{~m}^{2}\right)$ & 2 & 2 & 1 & 2 & 3 & 3 & & & & & & & & & & & & & \\
\hline Native richness $\left(4.5 / 0.25 \mathrm{~m}^{2}\right)$ & 1 & 1 & 1 & 2 & 2 & 2 & & & & & & & & & & & & & \\
\hline Exotic cover $(1.9 \%)$ & 4 & 3 & 2 & 7 & 6 & 5 & & & & & & & & & & & & & \\
\hline Native cover $(6.1 \%)$ & 2 & 2 & 2 & 3 & 3 & 2 & & & & & & & & & & & & & \\
\hline Brassica tournefortii cover $(0.1 \%)$ & 35 & 33 & 13 & 4 & & 7 & & & & & & & & & & & & & \\
\hline Bromus rubens cover $(0.1 \%)$ & 3 & 89 & 2 & 3 & & 0 & & & & & & & & & & & & & \\
\hline Erodium cicutarium cover $(0.8 \%)$ & 1 & 1 & 1 & 3 & 0 & 0 & & & & & & & & & & & & & \\
\hline Schismus arabicus cover (1.2\%) & 1 & 2 & 1 & 2 & 5 & 1 & & & & & & & & & & & & & \\
\hline \multicolumn{20}{|l|}{ Steers and Allen (2010) } \\
\hline Native richness $\left(4.5 / 0.5 \mathrm{~m}^{2}\right)$ & 1.1 & & & & & & & & & & & & & & & & & & \\
\hline Native cover $(23 \%)$ & 1.6 & & & & & & & & & & & & & & & & & & \\
\hline Exotic cover $(51 \%)$ & 1.3 & & & & & & & & & & & & & & & & & & \\
\hline Bromus rubens cover $(0.5 \%)$ & 7.4 & & & & & & & & & & & & & & & & & & \\
\hline Erodium cicutarium cover $(11 \%)$ & 0.7 & & & & & & & & & & & & & & & & & & \\
\hline Schismus spp. cover $(40 \%)$ & 1.4 & & & & & & & & & & & & & & & & & & \\
\hline Schismus spp. biomass $\left(308 \mathrm{~g} / \mathrm{m}^{2}\right)$ & 0.3 & & & & & & & & & & & & & & & & & & \\
\hline \multicolumn{20}{|l|}{ Abella et al. (2011) } \\
\hline Bromus rubens cover (1\%) & 9 & 5 & 9 & 19 & & 5 & 2 & 5 & 3 & 2 & 9 & 5 & 5 & 5 & 5 & 2 & 2 & & \\
\hline
\end{tabular}




\begin{tabular}{l}
\begin{tabular}{l}
\hline \\
Study and measure (interspace value) ${ }^{1}$
\end{tabular} \\
\cline { 2 - 4 } \\
\hline Schafer et al. $(2012)^{6}$
\end{tabular}

(Brooks, 2009). A total of 36 native perennial species were examined across all studies. Nine of the 10 studies included the evergreen shrub Larrea tridentata (the most commonly examined native perennial species), five included Ambrosia dumosa, three studies included Hymenoclea salsola, Krameria erecta, and Psorothamnus fremontii, and the remaining perennial species were included in two or fewer studies. Six studies reported abundance of individual exotic species, with a total of six exotic annual species examined representing predominant exotic annuals of the Mojave Desert. Eight studies examined at least the exotic Bromus rubens, and one study (Rodríguez-Buriticá and Miriti, 2009) focused on Schismus barbatus. Brooks (1999, 2000a) were the only studies reporting data for multiple years. In addition to exotic species data, five studies also reported native annual community measures or individual native species (Nelson and Chew, 1977; Brooks, 2000a; Craig et al., 2010; Steers and Allen, 2010; Schafer et al., 2012).

\subsection{Major principles of annual-perennial plant re- lationships}

The literature revealed several major principles. First, with few exceptions, most native perennial species supported a greater total abundance of exotic annuals than in interspaces (Table 1). However, the degree of facilitation varied by orders of magnitude among native perennial species within studies that compared multiple native species and among studies. Some of the native perennial species facilitating exotic annuals the least included Bebbia juncea, Encelia virginensis, Encelia farinosa, and in some studies, species such as Hymenoclea salsola and Ambrosia dumosa. All are drought-deciduous shrubs. Second, distributions of individual exotic species varied. Bromus rubens was usually most abundant below perennial plants compared to interspaces, whereas Schismus spp. and Erodium cicutarium were distributed more equitably between perennials and interspaces (Table 1, Fig. 3). Often, Schismus spp. and E. cicutarium were as or more abundant in interspaces than below perennials. Third, native annual community abundance and rich- 
ness exhibited below-perennial: interspace patterns that varied among studies. For example, Craig et al. (2010) found that the ratio of native cover was generally more equitable between below-perennial and interspace microsites than was exotic cover. In contrast, Steers and Allen (2010) found that native cover had a greater below perennial: interspace ratio than did exotic cover. Results were species-dependent for the seed bank study that included native annuals, with three native annual species exhibiting a lower below perennial:interspace ratio and one native annual species a higher ratio than the exotic annual Bromus rubens (Nelson and Chew, 1977).

\subsection{Mechanisms of relationships}

Interactions between plant species are often a balance of positive and negative effects (Holmgren et al., 1997). In the Mojave Desert, Holzapfel and Mahall (1999) partitioned positive and negative effects of the native perennial Ambrosia dumosa on exotic annuals, and vice versa. These authors found that Ambrosia had either strong positive or neutral effects on annual plant growth and reproduction, whereas the exotic annuals had strong negative or weak positive effects on $\mathrm{Am}$ brosia water status, growth, and reproduction. Rodríguez-Buriticá and Miriti (2009) found a similar result where shrubs overall facilitated exotic annuals that in turn reduced fitness of the shrubs. These experimental results are consistent with overall findings of the correlational studies reviewed here where exotic annual abundance was greater overall below native perennials than in interspaces, suggesting a net facilitation of exotic annuals by the native perennial community. Among the 10 studies, the only exception was Schafer et al. (2012) where exotic annual plant density was five-fold greater in interspaces than below Larrea tridentata.

The degree of facilitation of exotic annuals varied sharply among native perennial species, however, and not all perennial species harbored substantially more exotic annuals than interspaces. Traits of native perennial species that might influence the degree of facilitation remain elusive. Early research sought to assess significance of allelopathy in influencing facilitation by native perennials but found that a perennial (Ambrosia dumosa) harboring many annuals actually produced stronger allelopathic chemicals than a perennial (Encelia farinosa) harboring few annuals (Muller, 1953; Muller and Muller, 1956). This result, combined with the uncertain potency of the chemicals in natural desert soil, led these authors to conclude that allelopathy was not a strong influence. Plant size is often positively correlated with competitive ability in temperate regions, but in the Mojave Desert, there was no relationship between size of the perennial plant canopy and cover of the exotic annual Bromus rubens below (Abella et al., 2011). The extent and nature of fertile island formation by a native perennial, which might be more of a function of plant age than plant size, has been hypothesized to correlate with degree of facilitation (Abella et al., 2011, 2012). It is difficult to evaluate this hypothesis from current literature because soil properties have not been examined below most of the perennial species for which annual plant data are available, especially for perennial species (e.g. Encelia spp.) supporting among the fewest annuals (Romney et al., 1980; Titus et al., 2002; Thompson et al., 2005).

Related to fertile island ecology, perennial species that have the shortest life spans (usually species that are initial colonizers of disturbed areas) have also been hypothesized to minimally facilitate exotic annuals (Abella et al., 2012). Based on a compilation of life spans of some Mojave Desert perennial species (Bowers et al., 1997), at least in some studies the perennial species harboring the fewest exotic annuals were short lived. For example, the maximum life span of Bebbia juncea (which supported low amounts of exotic annuals) is approximately 20 years, compared to $>100$ years for Larrea tridentata which harbored more exotic annuals than interspaces in 7 of 8 studies. Many other traits, such as perennial plant canopy architecture, rooting habit, mycorrhizal associations, seasonality of growth, litterfall, and relationships with other biota, could relate to facilitative characteristics of native perennials, highlighting a need for further research to better mechanistically understand relationships between perennial plant traits and facilitation of exotic annuals (James et al., 2006; Abella et al., 2012; Su et al., 2012). 


\subsection{Exotic and native annual species distributions}

Intrinsically, beneath-perennial microhabitats should result in larger, denser populations of annuals because of the cooler, more mesic soil and surface conditions that occur there relative to open interspaces. Interspecific differences in spatial patterns of annual plants, though, might arise from annual species' functional traits. Comparative ecophysiological studies of Mojave Desert exotic annuals are rare, but we can surmise several traits that might lead to Bromus being more abundant beneath shrubs and Schismus and Erodium in interspaces. Brooks (2000a) noted that $B$. rubens is limited in the Mojave Desert by nutrients and water, a limitation that would be greater in interspaces (Titus et al., 2002). In contrast, Brooks (2000c) noted that Schismus spp. effectively compete with native annuals for limiting water and therefore populate interspaces more than fertile islands. Bromus is a fast-growing annual that has high leaf nitrogen content, and therefore photosynthetic rate, and higher transpiration rate (Smith et al., 1997; DeFalco et al., 2003). Another important factor is undoubtedly growth form - Bromus has a relatively upright architecture and germinates and rapidly grows early in the growing season (DeFalco et al., 2007), thus forming a canopy before competitors, whereas Schismus and Erodium have a more prostrate growth form that is susceptible to shading by not only shrub canopies but also by taller annuals. Indeed, Brooks (2000c) reported that Schismus is relatively intolerant of shading and mainly occurs under the south side of shrubs where tall annuals are less abundant. We add that the same phenomenon can occur in native annuals. For example, in the northern Mojave Desert, the tall-statured and fastgrowing Lepidium lasiocarpum occurs primarily beneath shrubs whereas Eriogonum trichopes, a slowergrowing annual with a basal-leaf rosette, is confined almost entirely to interspaces (Smith, unpublished data).

Another factor in these interspecific microhabitat differences could be seed germination and the relative maintenance of a soil seed bank. Seeds of annual Bromus spp. readily germinate when appropriate conditions exist (DeFalco et al., 2003), and they do not maintain a large, multi-year seed bank (Salo, 2004).
This makes them vulnerable to localized die-back under drought conditions. Although we have seen no comparative study that has addressed this, it is reasonable to predict that Bromus seed banks would persist to a greater degree in the moister soils of beneath-shrub microhabitats than in open interspaces where intense soil water stress can commence early in the growing season of dry years. In contrast, Schismus exhibits more of the bet-hedging strategy (only partial germination of the seed bank, even in wet years) that typifies most native desert annuals (Smith et al., 1997). Therefore, a bet-hedging strategy and generally lower water and nutrient requirements for plant growth and life cycle completion would typify annuals that populate interspaces, whereas higher nutrient and water requirements and higher germination fractions may typify annuals that primarily occur beneath perennials.

\subsection{Nurse plant effects}

We also observed that the large, evergreen shrub Larrea tridentata tended to harbor more annuals (relative to interspaces) than did the smaller drought-deciduous shrubs such as Ambrosia dumosa and Bebbia juncea. These differences in facilitation could be due to the relative ability of each shrub species to provide nutrients and moister soils beneath their canopies. For example, Larrea is much larger than Ambrosia in the Mojave Desert, and soils beneath Larrea canopies have higher phosphorous, soil organic matter, and most micronutrients than under Ambrosia (Titus et al., 2002). Although winter annuals primarily grow in the spring months when both evergreen and deciduous shrubs are leafed out, examination in the field suggests that these deciduous species often have sparser leaf canopies (and therefore cast less shade) than does the evergreen Larrea. A more important factor, however, could be plant age and therefore the "age" of the fertile island beneath the shrub. As shrubs age and grow in size, they attract more burrowing animals and also create more root channels for downward movement of water (Devitt and Smith, 2002). Larrea is an extremely long-lived plant, with many shrub clones being centuries old (Smith et al., 1997). Thus, these fertile islands of high nutrient and moisture content persist in the landscape. In contrast, Bebbia is an 
ephemeral shrub that does not form persistent fertile islands and therefore does not appear to "cultivate" a fertile-island-based annual flora. Ambrosia is intermediate between Larrea and Bebbia in community persistence, and therefore appears to have an intermediate response in annual plant populations within its canopy and in interspaces. Finally, it is worth noting that dense stands of Bromus can have a strong competitive effect on their perennial host plant, but this effect is least pronounced on the slow-growing, deeper-rooted Larrea (DeFalco et al., 2007), leading to the possibility that dense populations of Bromus have accelerated individual plant turnover in more vulnerable perennial grasses and low-statured shrubs.

\subsection{Other sources of variation: weather and site}

Weather in any given year and site factors (e.g. elevation) are two of the variables that could influence annual-perennial plant interactions, but their specific influences are not well understood. In the western Mojave Desert, Brooks (1999) found that the general pattern of greater Bromus rubens biomass below Larrea tridentata relative to interspaces was the same across dry (1994) and wet (1995) years. Schismus spp. and Erodium cicutarium, however, exhibited more biomass in interspaces than below Larrea in the dry year but more biomass below Larrea than in interspaces in the wet year. This switch in relative abundance could imply that with greater moisture availability, Schismus and Erodium were better able to exploit the nutrient-rich environment below Larrea than they could exploit in drier years when moisture was more limiting. However, the general conclusion that Bromus exhibited a larger below-perennial: interspace abundance ratio than did Schismus and Erodium was maintained across years (Table 1). Among-year variation in annual-perennial plant interactions could be important for other species and sites and warrants greater attention (Tielbörger and Kadmon, 1997; Ibáñez and Schupp, 2001). Similar to temporal variation in weather, elevation gradients can correlate with precipitation and soil resources and might induce variation in annual-perennial plant relationships (Brooks, 2009). For instance, abundance of exotic annuals that a given perennial species harbors relative to interspaces might change with elevation. Likewise, micro- microhabitat affinities of exotic annual species might shift with elevation, underscoring the importance of further evaluating spatial and temporal variation in annual- perennial plant relationships.

\section{Considerations for desert land man- agement and restoration}

Although other exotic annual species can supply fuel for wildfires and compete with native plants, Bromus rubens is particularly notorious in the Mojave Desert for producing copious and persistent fuels and being highly competitive with native species (Brooks, 2000a). Bromus rubens exhibited the highest overall below perennial:interspace abundance ratio, which does not necessarily imply that $B$. rubens always was sparse in interspaces, but rather that the species was exceptionally abundant below native perennial plants. Bromus rubens can facilitate combustion of the native perennials growing below by providing "ladder" fuel, and in areas where it infests interspaces, facilitating fire spread between perennial plants (Brooks, 2002). In mature desert communities, treatments to reduce $B$. rubens will require reducing it while maintaining native vegetation. Little research has examined effectiveness of $B$. rubens treatments, but Allen et al. (2005) found the species susceptible to the grass-specific herbicide Fusilade II on abandoned agricultural fields in California, USA. Fuel provided by other exotic annual species also can be significant in facilitating fire spread, and in some cases, fuel provided by species predominating in interspaces (e.g. Schismus spp.) can act synergistically with $B$. rubens fuel below native perennials to facilitate fire spread (Brooks, 2002). These observations suggest that fuel reduction treatments for exotic annuals may need to reduce multiple exotic annual species and be effective across a range of microsites, including in dense stands of native shrublands (e.g. Coleogyne ramosissima) where interspaces occupy small areas relative to most Larrea-Ambrosia desert scrub.

Species selection (choosing which native species to seed or plant or target for restoration) is a key consideration for revegetation and ecological restoration of disturbed lands, and the perennial plant microsite effect is also important in such decisions. In the Mojave 
Desert, major current disturbances of primary interest for restoration include wildfires, off-road vehicles, and renewable energy development (Abella, 2010). Results indicate that abundance of exotic annuals varies by orders of magnitude below different native perennial plants, suggesting a key role of native species selection for reducing hospitality to exotic species on restoration sites. Although many considerations (e.g. seed availability) affect species-selection decisions, results suggest that degree of facilitation of exotic species by native perennials is another consideration when choosing native perennial plants for restoration projects. It appears that native perennials that facilitate exotics the least tend to be early colonizing, shorter-lived, and minimal fertile-island forming species. It is not certain whether planting these native perennials would result in a tradeoff of reduced facilitation of native annuals. Moreover, such a tradeoff would need to be compared against the possibility of restoring a native perennial community that strongly facilitates establishment of exotic annuals, burns by wildfire, and is converted to an exotic annual-dominated community. An optimized restoration strategy might employ a range of native perennial species combined with treatments (e.g. herbicide) designed to reduce competitiveness of exotic annuals against both perennial and annual native species (Steers and Allen, 2010).

\section{Conclusions}

This review uncovered 10 studies that compared exotic annual plant abundance between interspaces and below native perennial plant species in the Mojave Desert. Collective results revealed that: (1) abundance of exotic annuals varied by orders of magnitude among native perennial species; (2) most perennial species harbored a greater abundance of exotic annuals than occurred in interspaces, but there were some native perennial species (e.g. Bebbia juncea) that harbored amounts similar to or less than interspaces in some studies; and (3) affinity for below-perennial or interspace microsites varied among exotic annual species, with Bromus rubens favoring below-perennial and Schismus spp. and Erodium cicutarium exhibiting more equitable distributions between microsites. Fur- ther research could evaluate additional native species, seek to identify causal mechanisms for why some native perennial species supported more exotic annuals than others, and assess broader-scale gradients (e.g. elevation) that might influence these fine-scale patterns. Considerations for the management and restoration of arid lands suggested by these results include developing treatments to reduce multiple exotic annual species across microsites and incorporating the degree of facilitation of exotic species in decisions regarding selection of native perennial species for restoration projects.

\section{Acknowledgements}

This work was facilitated by funding provided by cooperative agreements between the National Park Service (Lake Mead National Recreation Area, in particular Alice NEWTON) and the University of Nevada Las Vegas (UNLV) and was presented at the 2012 International Symposium on Invasive Plants and Global Change in Urumqi, China. We thank Sharon ALTMAN (UNLV) for creating Figs. 2 and 3; and Sharon ALTMAN, the associate editor, and two anonymous reviewers for helpful comments on the manuscript.

\section{References}

Abella S R, Engel E C, Lund C L, et al. 2009. Early post-fire plant establishment on a Mojave Desert burn. Madroño, 56: 137-148.

Abella S R. 2010. Disturbance and plant succession in the Mojave and Sonoran Deserts of the American Southwest. International Journal of Environmental Research and Public Health, 7: 1248-1284.

Abella S R, Craig D J, Chiquoine L P, et al. 2011. Relationships of native desert plants with red brome (Bromus rubens): toward identifying invasion-reducing species. Invasive Plant Science and Management, 4: $115-124$.

Abella S R, Craig D J, Smith S D, et al. 2012. Identifying native vegetation for reducing exotic species during the restoration of desert ecosystems. Restoration Ecology, 20: 781-787.

Allen E B, Cox R D, Tennant T, et al. 2005. Landscape restoration in southern California forblands: response of abandoned farmland to invasive annual grass control. Israel Journal of Plant Sciences, 53: 237-245.

Allen E B, Steers R J, Dickens S J. 2011. Impacts of fire and invasive species on desert soil ecology. Rangeland Ecology and Management, 64: $450-462$. 
Barrows C W, Allen E B, Brooks M L, et al. 2009. Effects of an invasive plant on a desert sand dune landscape. Biological Invasions, 11: 673-686.

Bhark E W, Small E E. 2003. The association between plant canopies and the spatial patterns of infiltration in shrubland and grassland of the Chihuahuan Desert. Ecosystems, 6: 185-196.

Bonanomi G, Incerti G, Mazzoleni S. 2011. Assessing occurrence, specificity, and mechanisms of plant facilitation in terrestrial ecosystems. Plant Ecology, 212: 1777-1790.

Bowers J E, Webb R H, Pierson E A. 1997. Succession of desert plants on debris flow terraces, Grand Canyon, Arizona, USA. Journal of Arid Environments, 36: 67-86.

Brooks M L. 1999. Habitat invasibility and dominance by alien annual plants in the western Mojave Desert. Biological Invasions, 1: 325-337.

Brooks M L. 2000a. Competition between alien annual grasses and native annual plants in the Mojave Desert. American Midland Naturalist, 144: 92-108.

Brooks M L. 2000b. Bromus madritensis ssp. rubens (L.) Husnot. In: Bossard C C, Randall J M, Hoshovsky M C. Invasive Plants of California's Wildlands. Berkeley: University of California Press, 72-76.

Brooks M L. 2000c. Schismus arabicus Nees and Schismus barbatus (L.) Thell. In: Bossard C C, Randall J M, Hoshovsky M C. Invasive Plants of California's Wildlands. Berkeley: University of California Press, 287-291.

Brooks M L. 2002. Peak fire temperatures and effects on annual plants in the Mojave Desert. Ecological Applications, 12: 1088-1102.

Brooks M L, Berry K H. 2006. Dominance and environmental correlates of alien annual plants in the Mojave Desert, USA. Journal of Arid Environments, 67: 100-124.

Brooks M L. 2009. Spatial and temporal distribution of non-native plants in upland areas of the Mojave Desert. In: Webb R H, Fenstermaker L F, Heaton J S, et al. The Mojave Desert: Ecosystem Processes and Sustainability. Reno: University of Nevada Press, 101-124.

Craig D J, Craig J E, Abella S R, et al. 2010. Factors affecting exotic annual plant cover and richness along roadsides in the eastern Mojave Desert, USA. Journal of Arid Environments, 74: 702-707.

De Soyza A G, Whitford W G, Martinez-Meza E, et al. 1997. Variation in creosotebush (Larrea tridentata) canopy morphology in relation to habitat, soil fertility and associated annual plant communities. American Midland Naturalist, 137: 13-26.

DeFalco L A, Bryla D R, Smith-Longozo V, et al. 2003. Are Mojave Desert annual species equal? Resource acquisition and allocation for the invasive grass Bromus madritensis subsp. rubens (Poaceae) and two native species. American Journal of Botany, 90: 1045-1053.

DeFalco L A, Fernandez G C J, Nowak R S. 2007. Variation in the establishment of a non-native annual grass influences competitive interactions with Mojave Desert perennials. Biological Invasions, 9: 293-307.
Devitt D A, Smith S D. 2002. Root channel macropores enhance downward movement of water in a Mojave Desert ecosystem. Journal of Arid Environments, 50: 99-108.

Esque T C, Schwalbe C R. 2002. Alien annual grasses and their relationships to fire and biotic change in Sonoran desertscrub. In: Tellman B. Invasive Exotic Species in the Sonoran Region. Tucson: University of Arizona Press and Arizona-Sonora Desert Museum, 165-194.

Flores J, Jurado E. 2003. Are nurse-protégé interactions more common among plants from arid environments? Journal of Arid Environments, 14: 911-916.

Franco A C, Nobel P S. 1989. Effect of nurse plants on the microhabitat and growth of cacti. Journal of Ecology, 77: 870-886.

Garner W, Steinberger Y. 1989. A proposed mechanism for the formation of 'fertile islands' in the desert ecosystem. Journal of Arid Environments, 16: 257-262.

Holmgren M, Scheffer M, Huston M A. 1997. The interplay of facilitation and competition in plant communities. Ecology, 78: 1966-1975.

Holzapfel C, Mahall B E. 1999. Biodirectional facilitation and interference between shrubs and annuals in the Mojave Desert. Ecology, 80: $1747-1761$.

Holzapfel C, Tielborger K, Parag H A, et al. 2006. Annual plant-shrub interactions along an aridity gradient. Basic and Applied Ecology, 7: 268-279.

Ibáñez I, Schupp E W. 2001. Positive and negative interactions between environmental conditions affecting Cercocarpus ledifolius seedling survival. Oecologia, 129: 543-550.

James J J, Caird M A, Drenovsky R E, et al. 2006. Influence of resource pulses and perennial neighbors on the establishment of an invasive annual grass in the Mojave Desert. Journal of Arid Environments, 67: 528-534.

McAuliffe J R. 1988. Markovian dynamics of simple and complex desert plant communities. American Naturalist, 131: 459-490.

Muller C H. 1953. The association of desert annuals with shrubs. American Journal of Botany, 40: 52-60.

Muller W H, Muller C H. 1956. Association patterns involving desert plants that contain toxic products. American Journal of Botany, 43: 354-361.

Nelson J F, Chew R M. 1977. Factors affecting seed reserves in the soil of a Mojave Desert ecosystem, Rock Valley, Nye County, Nevada. American Midland Naturalist, 97: 300-320.

Padilla F M, Pugnaire F I. 2006. The role of nurse plants in the restoration of degraded environments. Frontiers in Ecology and the Environment, 4: 196-202.

Patten D T. 1978. Productivity and production efficiency of an upper Sonoran Desert ephemeral community. American Journal of Botany, 65: 891-895.

Rodríguez-Buriticá S, Miriti M N. 2009. Biting the hand that feeds: the invasive grass Schismus barbatus (Poaceae) is facilitated by, but reduces establishment of, the native shrub Ambrosia dumosa (As- 
teraceae). Journal of Vegetation Science, 20: 241-250.

Romney E M, Wallace A, Kaaz H, et al. 1980. The role of shrubs on redistribution of mineral nutrients in soil in the Mojave Desert. Great Basin Naturalist Memoirs, 4: 124-133.

Rundel P W, Gibson A C. 1996. Ecological Communities and Processes in a Mojave Desert Ecosystem: Rock Valley, Nevada. New York: Cambridge University Press.

Salo L F. 2004. Population dynamics of red brome (Bromus madritensis subsp. rubens): times for concern, opportunities for management. Journal of Arid Environments, 57: 291-296.

Schlesinger W H, Raikes J A, Hartley A E, et al. 1996. On the spatial pattern of soil nutrients in desert ecosystems. Ecology, 77: 364-374.

Smith S D, Monson R K, Anderson J E. 1997. Physiological Ecology of North American Desert Plants. Berlin: Springer-Verlag.

Steers R J, Allen E B. 2010. Post-fire control of invasive plants promotes native recovery in a burned desert shrubland. Restoration Ecology, 18(S2): 334-343.

Tewksbury J J, Lloyd J D. 2001. Positive interactions under nurse-plants: spatial scale, stress gradients and interference in desert plants. Ecol-
Ecology, 81: 1544-1553.

Thompson D B, Walker L R, Landau F H, et al. 2005. The influence of elevation, shrub species, and biological soil crust on fertile islands in the Mojave Desert, USA. Journal of Arid Environments, 61: 609-629.

Tielbörger K, Kadmon R. 1997. Relationships between shrubs and annual communities in a sandy desert ecosystem: a three-year study. Plant Ecology, 130: 191-201.

Titus J H, Nowak R S, Smith S D. 2002. Soil resource heterogeneity in the Mojave Desert. Journal of Arid Environments, 52: 269-292.

Went F W. 1942. The dependence of certain annual plants on shrubs in southern California deserts. Bulletin of the Torrey Botanical Club, 69: $100-114$.

Yin C H, Feng G, Zhang F S, et al. 2010. Enrichment of soil fertility and salinity by tamarisk in saline soils on the northern edge of the Taklimakan Desert. Agricultural Water Management, 97: 1978-1986.

Su Y Z, Wang X F, Yang R, et al. 2012. Soil fertility, salinity and nematode diversity influenced by Tamarix ramosissima in different habitats in an arid desert oasis. Environmental Management, 50: 226-236. 